Journal of Educational Research in Developing Areas (JEREDA)

Vol. 2. Issue 1, Pp. 24-33, 2021

http://www.jeredajournal.com

E-mail: info@jeredajournal.com

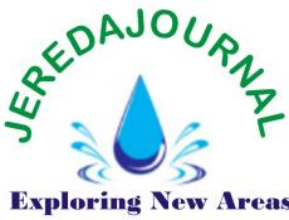

Research Article DOI: https://doi.org/10.47434/JEREDA.

eISSN: $2735-9107$

\title{
TASK-ORIENTED LEADERSHIP STYLE ON STUDENTS' ACADEMIC ACHIEVEMENT IN PUBLIC SECONDARY SCHOOLS IN NYERI COUNTY, KENYA
}

\section{1*Macharia Samuel Wanyoko, 2Peter Nyaga Muchanje}

1,2Department of education Management, Policy and Curriculum Studies, Kenyatta University, Kenya ${ }^{1}$ wanysam@gmail.com;²muchanje.peter@ku.ac.ke

*Corresponding author: ${ }^{1}$ wanysam@gmail.com

(10) https://orcid.org/0000-0001-8759-884X

Received:15 $5^{\text {th }}$ March, 2021; Revised:22 ${ }^{\text {nd }}$ March, 2021; Accepted: $3^{\text {rd }}$ April, 2021

ABSTRACT
Introduction: The concept of school leadership has attracted the attention of many stakeholders in education sector. Students' academic achievement is greatly determined by the decisions made by the school governance. The leadership style used by leaders influences the decision making process, communication process and implementation of decisions made.

Purpose: The study sought to find out the extent to which task-oriented leadership style used by school heads in public secondary schools in Nyeri Central Sub-County affects students' academic achievement.

Methodology: The study used descriptive research design to obtain accurate information concerning the current existing phenomena. The sample consisted 590 statistically sampled using Krejcie's and Morgan's table of sampling. Data was collected using structured questionnaires and interview schedules. After pilot study, the researcher checked validity and reliability of the tools. The reliability value of the tool was 0.8 . To enhance consistency of the tool, test-retest reliability technique was used and yielded a coefficient of 0.76. Pearson's Correlation Coefficient was used to determine the relationship between task-oriented leadership style and students' academic achievement.

Results: The study found that principals who practiced task-oriented leadership style posted high mean mark in Kenya Certificate of Secondary Education (KCSE). The study also revealed that majority of principals practiced relationship-oriented leadership style hence, it was the most prevalent leadership style in Nyeri Central Sub-County. The study found a strong positive correlation between task-oriented leadership style and students' achievement.

Recommendations: It is recommended that principals' should incorporate different leadership styles depending on the situation at hand to promote high students achievement.

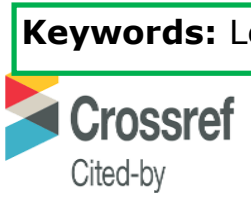

\section{Cite paper as:}

Wanyoko, M. S., \& Muchanje, P. N. (2021). Task-oriented leadership style on students' academic achievement in public secondary schools in Nyeri county, Kenya. Journal of Educational Research in Developing Areas, 2 (1), 24-33. https://doi.org/10.47434/JEREDA.2.1.2021.24.

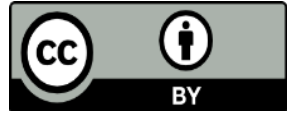

Copyright (c) 2021 The author(s) of this article retain(s) the copyright. 


\section{PUBLIC INTEREST STATEMENT}

Despite the government's effort to offer free day secondary education, subsidised secondary education for boarding schools and providing funds for cocurricular activities, students' achievements is still low in KCSE. From this study, school principals will be charged with the responsibility of supervising the curriculum implementation, setting organizational goals and providing a good environment to promote students' success. Parents and other stakeholders in the education sector will be relieved of their concerns with the low performance despite playing their role in paying fees in boarding schools and providing necessary support required. The present trend will make it imperative to find out whether task-oriented leadership style affects students' performance in schools. The study will bridge the gap on the existing inconsistencies from the previous studies to find out the effect of task oriented leadership style on students' achievement.

\section{INTRODUCTION}

School leadership is important as it provides direction to the institution. It is the dream of every leader to achieve the set goals and attain success. In order to achieve the set objectives, it requires a school leader to offer direction to the teachers, students and other members of staff in the school working for the benefit of the students. For school leaders to achieve the set goals, great co-operation is required between teachers and the administration. Principals steer the schools in the direction they want them to go because they are the major decision makers in the school. Task-oriented leadership is a leadership that is imposed in an institution and is coercive in nature. Wang and Guan (2018) notes that taskoriented leaders have all the control of decisions in an organization and makes choices depending on their ideas and preferences and do rarely allow subordinates to contribute in decision making. Task-oriented leaders provide clear expectations of what is to be done and how it should be done. They make decisions independently with or with no input from their subordinates. Taskoriented leaders outline tasks to be done and demand error free results. Principals who are authoritarian make all decisions to be followed, supervise them and are only concerned with the job processes. Okumbe (2001) describes task-oriented personnel as those with no concern on the welfare of the workers. He or she is workaholic and has no confidence in his or her subordinates.

The effectiveness of a school leader is measured by students' success in academics. Zhao (2010) accords that school leadership and students' achievement are global issues. Taskoriented leaders are interested in the productivity of staff with little concern on the welfare of workers. This type of leadership stresses the use of authority to control the subordinates. Taskoriented leadership demotivates employees who feels need for inclusion in contribution of organizations policy. On the other hand task-oriented leadership is effective in institutions where subordinates are lazy and with low productivity. Chan (2014) concurs that task-oriented leadership is essential when there is too much freedom in the institution and low productivity from workers.

In studies on task-oriented leadership style by Chan (2014), taskoriented leadership is negatively related to the employee performance because subordinates of authoritarian leadership are likely to have low levels of trust in the principals, school-based esteem and little motivation to improve on their performance. To fully understand the effect of task-oriented leadership style on students' academic achievement, it is critical to investigate the mechanism of task-oriented leadership. For example, the level of motivation of employees, leader-member relationship and methods 
of communication of task to be performed. Wang and Guan (2018) argues that effects of principals' taskoriented leadership style on teachers depend on certain conditions and may influence the relationship between taskoriented leadership and students' achievement. A study carried out in the USA on teachers' perception of principals' leadership styles on students' achievement by Hardman (2011) found that principals' leadership styles affects students' achievement positively. School leaders who are able to maintain a high level of interpersonal skills among teachers have a lot of influence and easily motivate the teachers to give their best during curriculum implementation. In the global arena, Teri, Barbara and Lucindia (2013) of USA in a study on leadership and students' achievement across societal cultures found that leadership approaches that principals applies are significant in predicting students' achievement. Principals'taskoriented leadership style influences the relationship with teachers and decision making process. Schools have many objectives to achieve but emphases is always placed on the students' achievement in academics and in cocurricular activities. The expectation of parents is excellent achievement of their children. Adeyemo (2001) notes that the major goal of the school is to work towards attainment of academic excellence by students.

In Punjab Pakistan, a study done by Kearns, Murphy and Villiers (2006) to examined how leadership style impacts on the academic performance of students in Grade 10 revealed that the leadership style used to a great extent influences the learners' achievement. School leaders are usually keen to ensure fair resource distribution according to the $21^{\text {st }}$ Century standards. Kearns et. al (2006) concluded that leaders have an additional task related to students' achievement and the necessary skills to guide those who are entrusted with learning and achievement of students. The success of an educational institution is realized from the efficiency of teaching and learning processes.
Both teachers and students perform their roles under the leadership of the principal. Task-oriented leaders have poor interpersonal relationship with the subordinates. This creates a big gap between leaders and subordinates and may may fail to meet organizational goals. Aldag (2001) accords that taskoriented leadership is not the most favoured one in the ditto century organizations as expressed by consensus of several leadership theorists. Because authoritarian leaders decides everything themselves and executes it their own way, they do not give employees the chance to spin on the task performed. According to Yusuf (2012), no school can be greater than its leader. School principals must be able to incorporate and balance all tasks entrusted to their responsibility.

A study in Australian secondary schools (OECD, 2003) found out that leadership impact is predominantly related to the students' academic achievement via the more direct influence exerted upon the way in which teachers organize and conduct their instruction. The study also highlighted influential factors that could affect learning of students. These factors included among others the leadership styles used and relationship of the school with the surrounding community. Moffitt (2007) indicated that principals should balance interests of various groups to enhance cohesion and promote team work. A study conducted in Delta State of Nigeria by Duze (2012) on leadership styles of principals and job performance of staff reported that job performance of staff was affected by leadership styles: autocratic, democratic and transformational to greater and lesser extents depending on the prevailing circumstances of the school. Duze (2012) alludes that most principals, however, have not considered the effect of leadership style on teachers' job performance and by extension students' academic achievement. Leadership styles occupy a great position in school management.

Yahya (2015) notes that the principal is responsible for schools 
general development and improvement in students' academic achievement, in that, an effective school leader creates an environment that stimulates enthusiasm for learning. A study conducted by Harerimana and Adegoke (2017) in Kigali Rwanda on influence of leadership styles on students' achievement found that leadership styles influenced students' achievement in academics, where relationship-oriented leadership style was found to be more influential to performance of students in selected schools than task-oriented leadership style. The study revealed that majority of the principals applied relationshiporiented leadership style while few applied task-oriented leadership style. In Kenya, a study done by Budohi (2014), on effect of principals' leadership style on students' academic achievement established that use of effective leadership styles enhance high students' achievement. The role of school head teacher is to provide guidance and steer the organization to achieving organizational goals. The role of school head teachers has changed over time, more responsibilities have trickled in and critical decisions have to be made in all administrative actions. A study by Kabuchi and Gitau (2010) on influence of head teachers' leadership style on pupil performance in Kenyan public primary schools established that there was a significant relationship between head teachers leadership style and students' achievement. Additionally, these researchers found that the most prevalent leadership style applied by head teachers was relationship-oriented leadership style while few head teachers applied task-oriented leadership style.

Similar study carried out in Homabay, Kenya by Obama, Eunice and Orodho, (2014), established that there is a high relationship between the leadership of principals of secondary schools and students' achievement. The study established that schools that encouraged participative leadership styles had highly motivated staff. In the same study, it was revealed that autocratic leaders are highly centralised on power and are described as dictatorial thus reducing teachers' morale and in the long run lower students' achievement. Studies on leadership styles and students' achievement by Okoth (2000) and Kitavi (2014) revealed that principals who were rated as task-oriented leaders had a low performance mean in Kenya Certificate of Secondary Education (KCSE). Though studies by Wangui (2007) and Muli (2005) on leadership styles on students' performance found that leadership style that a principal uses influences students' achievement where task-oriented leaders posted high mean scores in KCSE. The researcher found it important to carry out the study to bridge the gap on the existing inconsistencies from the previous studies to find out the effect of task oriented leadership style on students' achievement.

In light of this background, the study was carried out in Nyeri Central Sub-County where there was a notable low students' achievement in Kenya Certificate of Secondary Education (KCSE), where in 2018, out of 2073 students who sat for the KCSE, 600 students' scored the lowest grade $\mathrm{E}$. There has been a dwindling academic performance except for the year 2017 which had a negligible improvement. This low performance according to Hardman (2011) may result to wastage where many students score grades that cannot admit them in Diploma and Certificate colleges. Despite the government's effort to offer free day secondary education, subsidised secondary education for boarding schools and providing funds for co-curricular activities, students' achievements is still low in KCSE. School principals are charged with the responsibility of supervising the curriculum implementation, setting organizational goals and providing a good environment to promote students' success. The principal's administrative style influences decision making process, leader-staff relations and working environment in the school. Parents and other stake holders in the education sector are concerned with the low performance despite playing their role in paying fees in boarding schools and providing necessary support required. 
The present trend made it imperative to find out whether task-oriented leadership style affects students' performance in academics.

\section{Theoretical Framework}

The study is guided by contingency theory of leadership developed by Fred Fiedler which states that there is no one best leadership style, and that the effectiveness of a leader is dependent on the situation at hand and the leadership style. In this model, leader-member relations, task structure and leaders positional power are key elements to the situational favourableness of the leader. This theory was choosen to guide the study because the concepts it addresses are in line with the concepts addressed by this study. The situation in an institution dictates the type of leadership style to use to effectively manage staff and achieve set organizational goals.

\section{STATEMENT OF THE PROBLEM}

Students' academic achievement is imperative as it serves as a point of reference to promotion to the next level of education. Pursuant to the background, the performance in KCSE in Nyeri Central Sub-County has been low compared to the county's overall KCSE mean score. Data from Nyeri Central Sub-County office (2019) indicate that for the years 2015-2019, the KCSE mean for the Sub-County has been low compared to County's KCSE mean, except for the year 2017 where the SubCounty's mean was slightly higher than the county's overall mean. The low performance in Nyeri Central Sub-County has been well pronounced with high number of students scoring the lowest grade $\mathrm{E}$ in KCSE. This low academic achievement places students' in this SubCounty at a lower competitive advantage hence they miss opportunities to join middle level colleges for Certificate and Diploma courses. If this trend is not checked, the government's effort in providing free day secondary education, employing qualified graduate teachers and using Constituency Development Funds (CDF) to give bursaries to students and renovate school infrastructure will not benefit students to useful citizens. The low performance in academics have started to raise alarm and various stakeholders have continued to raise accusing fingers on the management of leadership style used by principals to manage their schools.

The government of Kenya has put effort to develop goals and objectives and in line with Education For All (EFA) and Kenya vision 2030 to train principals and equip them with leadership skills at Kenya Education Management Institute (KEMI). This condition coupled with the low performance in Nyeri Central SubCounty warranted the researchers to investigate whether the principals' taskoriented leadership style affects students' achievement in the said Sub-County.

\section{PURPOSE OF THE STUDY}

The study sought to find out if the task-oriented leadership style used by school heads in public secondary schools in Nyeri Central Sub-County affects students' achievement in academics to any extent.

\section{RESEARCH QUESTION}

1. To what extent does task-oriented leadership style affect students' academic achievement in public secondary schools in Nyeri Central Sub-County?

\section{METHODOLOGY \\ Research Design}

The study was carried out using a descriptive research design. The use of descriptive research design was appropriate in this study because it enabled the researchers gather original data from the respondents about their attitudes, behaviours and perception to be able to describe the existing phenomena on principals' leadership styles.

\section{Population and Sample}

There were 22 public secondary schools, 22 principals and 490 teachers in Nyeri Central Sub-County.Schools were stratified by categories namely boys boarding schools, girls boarding school, 
mixed day schools and mixed boarding schools. Schools to be included in the sample were selected by simple random sampling. All principals of the sampled schools were included in the sample. Teachers were stratified by gender and then randomly selected. Stratified random sampling was appropriate for this study because it reduces the chances of bias and also ensures that samples in different strata are not underrepresented or overrepresented. Teachers were chosen to be respondents of the study because they are aware of principals' leadership strategies in policy implementation, leader-member relationships and supervision strategies.

Principals were chosen to be respondents of the study because it is their leadership style that influences decision making process and hence rise or fall of an institution. Using Krejcie's and Morgan's table of sampling, 214 teachers and 19 principals formed part of the sample size yielding a total of 233 respondents. Krejcie's and Morgan's method of determining sample sizes was appropriate in this study because of its minimum margin error, a higher confidence level and the fact that the population was small.

\section{Instrument for Data Collection}

The study used questionnaire to collect primary data to enable the study answer the research question and achieve study objectives. The researchers developed structured questionnaire and an interview schedule to collect information from teachers and principals. To validate and check the reliability of the instrument, a pilot study was done in two schools randomly selected from schools which were not part of the sample size. This was test the efficacy of data collection tools with an aim of correcting errors and identifying weakness of the tools. The data was used to check both content and construct validities. This was done by ensuring that the indicators and measurement of leadership style were carefully developed based on relevant existing knowledge. Questionnaire was scrutinized to contain relevant questions that would enable the study measure indicators of leadership style. Items that did not meet the criteria were revised or removed from the instrument. To enhance consistency of the tool, test-retest reliability technique was used. Using Person's Product Moment Correlation formula, a coefficient of 0.76 was found. This was deemed acceptable as indicated by Hardman (2011) that a coefficient of between 0.7 to 0.9 is sufficient.

\section{Method for Data Analysis}

Quantitative data obtained was organized using Statistical Package for Social Science (SPSS) Version 24 and data presented using tables. Pearson's Correlation was the main method of analysis used to determine the relationship between task-oriented leadership style and students' achievement. Data obtained after analysis was used to answer research question by comparing the coefficients obtained with the ratings given to various variables.

\section{RESULTS}

Research Question 1: To what extent does task-oriented leadership style affect students' academic achievement in public secondary schools in Nyeri Central SubCounty?

The objective of the study was to determine the effect of task-oriented leadership style on students' academic achievement. Principals were requested in the questionnaire to state the KCSE mean scores for the years 2015-2019. An analysis on KCSE mean scores for the years 2015-2019 in relation to different leadership styles was conducted.Data analysed was presented in Table 1 . 
Journal of Educational Research in Developing Areas (JEREDA)

Vol. 2. Issue 1, Pp. 24-33, 2021

http://www.jeredajournal.com

E-mail: info@jeredajournal.com

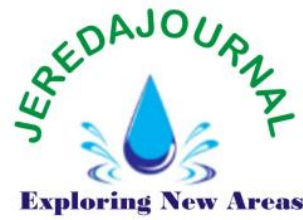

Table 1 Leadership Styles and Students' KCSE Peformance

\begin{tabular}{ll}
\hline $\begin{array}{l}\text { Principals } \\
\text { Leadership Style }\end{array}$ & $\begin{array}{l}\text { KCSE } \\
\% \text { Mean }\end{array}$ \\
\hline Task-oriented & 65 \\
Relationship-oriented & 35 \\
\hline
\end{tabular}

Schools where principals practiced task-oriented leadership style were found to have high mean in KCSE at 65 per cent while principals who were practicing relationship-oriented leadership style were found to post lower mean in KCSE at 35 per cent. This means that principals who were focused on goal achievement, with centralised command and who were sole decision makers in the school were able to manage teaching-learning process well and hence students achieved high scores in academics. These findings concur with findings from a separate study by Huka (2003) who found out that task-oriented leadership style was associated with high students' achievement.

Principals were requested to state in the questionnaire the type of leadership they apply in their schools. Teachers were also requested to state the type of leadership their principals uses. Data obtained revealed that majority of teachers at 58 per cent rated their principals as relationship-oriented leaders while 44 per cent of teachers rated their principals as task-oriented leaders. Majority of principals at 65 per cent rated themselves as relationshiporiented leaders while 35 per cent of principals rated themselves as taskoriented leaders. The most prevalent leadership style therefore was relationship-oriented with $61.63 \%$ prevalence.

The effect of task-oriented leadership style on students' achievement was determined by obtaining the mean performance of the schools in KCSE (2015-2019) and mean values for task-oriented leadership style in each school. Pearson's Correlation Coefficient was used to determine the relationship between task-oriented leadership style and students' achievement. Analysed data is as presented in Table 2

Table 2: Correlation Analysis of the relationship between Task-Oriented Leadership style and students' KCSE Performance.

\begin{tabular}{|c|c|c|c|}
\hline Correlations & & $\begin{array}{r}\text { Task-Oriented } \\
\text { Leadership Style }\end{array}$ & $\begin{array}{l}\text { KCSE Mean } \\
\text { Scores }\end{array}$ \\
\hline \multirow{3}{*}{$\begin{array}{l}\text { Task-Oriented } \\
\text { Leadership Style }\end{array}$} & Pearson & 1 & 0.99 \\
\hline & $\begin{array}{l}\text { Correlation } \\
\text { Sig.(2-tailed) }\end{array}$ & & .001 \\
\hline & $\mathrm{N}$ & 169 & 169 \\
\hline \multirow[t]{3}{*}{ KCSE Mean Scores } & $\begin{array}{l}\text { Pearson } \\
\text { Correlation }\end{array}$ & 0.99 & 1 \\
\hline & Sig. (2-tailed) & .001 & \\
\hline & $\mathrm{N}$ & 169 & 169 \\
\hline
\end{tabular}


The Correlation Coefficient $r$ obtained was 0.99 is statistically significant. The value of significance obtained was 0.001 which is lower than 0.05 confidence level hence the relationship is statistically significant. The 0.99 correlation coefficient obtained indicates a strong positive correlation between task-oriented leadership style and students' academic achievement. Hence task-oriented leadership style affects students' achievement.

\section{DISCUSSIONS}

The findings of this study indicates that principals who use task-oriented leadership style impacts greatly on the success or failure of a learner. Given that task-oriented leaders unilaterally makes all decisions in the school, are keen on schedules, and expects staff to follow instructions without much debate, these impacts on the teachers' response in implementation of curriculum guidelines because the leaders are not concerned with teachers welfare. Therefore, the success of a learner is dependent on the teachers' ability to guide students in the learning process. Bennis (2013) accords that task-oriented leadership is advantageous as it compels workers to work quickly for high production.

The findings in this study reveals that principals are key to development of a strong instructional leadership and increasing students' achievement at the same time maintaining students' behaviour. This means that principals are responsible for everything that happens in the institutions. The success or failure of an institution is dependent on the principals' leadership style which influences decision making process and the teachers working environment. Yambo (2012) in a different study found that principals were central to successful management of educational institutions and implementation of curriculum in totality. The study revealed that taskoriented leadership style is critical in determining the leaders overall leadership character. This implies that the conclusion in relation to the study research question on effect of taskoriented leadership style on students' achievement, that the decision making, working environment, freedom and job autonomy in schools are greatly influenced by task-oriented leadership style. In concurrence Huka (2003) found that task-oriented leadership style influenced principals' decision making, where principals focused on goal achievement, meeting deadlines which resulted to high students' academic achievement.

Task-oriented leadership style is important for implementing the matter at hand when it requires immediate action. This makes teachers get out of their comfort zones and meet up with the demands given by principals. Taskoriented leader does not necessarily need to involve teachers directly in the school. $\mathrm{S} /$ he can influence the working behaviour attitudes by encouraging the teachers to follow by example. The study established that task-oriented leadership impacts to students, more than relationship-oriented style.

The leadership patterns enables the principals to demonstrate leadership competencies by understanding the nature of school, staff and students. Since good leaders are always judged by their relational approaches, it is equally vital for the leaders to demonstrate taskoriented behaviour for school effectiveness even though this approach may not be desired by teachers. Moreover, the correct balancing of leadership styles must be demonstrated to gain leadership competencies.

\section{CONCLUSION}

Based on the findings, schools where principals practiced task-oriented leadership style were found to post high mean marks in KCSE. Pearson's Correlation Coefficient $r$ obtained from the analysed data revealed that there is a strong positive correlation between taskoriented leadership style and students' academic achievement. Task-oriented leadership style was therefore found to positively affect students' achievement in academics. 


\section{RECOMMENDATIONS}

Based on the study findings, the following recommendations were made:

1. Teachers Service Commission may organize in-service programmes organized to equip newly elected principals and the one on the job with skills to improve their knowledge on human resource as well as administrative skills.

2. That principals may be more flexible in adopting a leadership style that will enable the employees feel a sense of belonging, be motivated, and promote a collaborative working environment.

Conflicts of Interest: The authors declare no conflict of interest.

\section{Acknowledgement}

The researchers acknowledge the university supervisor Peter Nyaga Muchanje, Department of Education Management, Policy and Curriculum Studies, Kenyatta University.

\section{Disclaimer Statement}

This work is part of masters project submitted at Kenyatta University, examined and passed.

\section{Notes on Authors}

Macharia Samuel Wanyoko is a post graduate students at Kenyatta University who is set to graduate in July 2021.

Peter Nyaga Muchanje is a lecturer at the Department of Education Management, Policy and Curriculum Studies, Kenyatta University.

\section{Authorship and Level of Contribution} Macharia Samuel Wanyoko co-authored with my supervisor Peter Nyaga Muchanje

\section{REFERENCES}

Adeyemo, D. A. (2001). Teachers' job satisfaction, job involvement, career and organizational commitments as correlates of student-academic performance. Nigerian Journal of Applied Psychology, 6 (2), 126-135.
Aggrawal, Y. P. (2008). Education in emerging indian society handbook. Anshah.

Aldag, R. (2001). Organizational behaviour and management: An integrated skills approach. WEA South Western.

Bennis, W. (2013). Becoming a leader. Basic Books

Budohi, L. A. (2014), The effect of principals leadership style on the academic achievement of students' in public secondary schools in Lurambi division, Kakamega. Unpublished Masters of Education Project. Kenyatta University.

Chan, S. C. (2014). Paternalistic leadership and employee voice: Does information sharing matter? Human Relations, 67(6), 623633.

Duze, C.O. (2012). Leadership styles of principals and job performance of staff in secondary schools in Delta State of Nigeria. An International Journal of Social Arts and Humanities. 1(2), 34-45.

Harerimana, J. P., \& Adegoke, O. T. (2017). Investigation on the influence of leadership

styles on students' academic performance in selected secondary schools: $A$ case study of Gosabo district, Kigali, Rwanda. A journal of Research and Method in Education,7, 1821.

Hardman, B. K. (2011). Teacher's perception of their principal's leadership style and the effects on student achievement in improving and non-improving school (2011). Graduate Thesis and Dissertation. https://scholarcommons.usf.edu/e td/3726

Huka, M. D. (2003). A study of head teachers' management styles and performance of KCSE examination in Mandera district. Unpublished Master of Education Project, University of Nairobi.

Kabuchi, S. N., \& Gitau P. K. (2010). Influence of head teachers' leadership styles on pupils' 


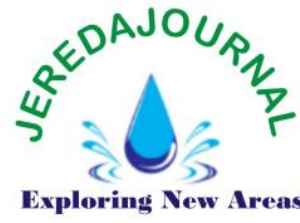

performance at Kenya certificate of primary education in west lands district. Unpublished Masters of Education project, University of Nairobi.

Kearns, P., Murphy, M., \& Villiers, G. (2006). Industry education partnership: Innovation and learning. The report. Office of Training and Further Education, 1(2), 34-36.

Kitavi, M. J. (2014). Influence of head teachers' leadership on pupils performance at Kenya certificate of primary education in Matinyani Sub-County, Kitui County Kenya. Unpublished Masters of Education Project, University of Nairobi.

Moffitt, J. R. (2007). What works: principal leadership behaviours that positively impact student achievement in elementary schools. Electronic Theses \& Dissertations. 264. https://digitalcommons.georgiaso uthern.edu/etd/264.

Muli, M. M. (2005). Effects of headteachers' management styles on performance in Physics at KCSE examinations in Mutomo Division, Kitui District. Unpublished Masters of Education Project, University of Nairobi.

Obama, M. O., Eunice, L. A., \& Orodho, J. A. (2014). Effects of principals' leadership style on students' academic performance in public secondary schools in Homabay County, Kenya. Journal of Humanities and Social Science, 2, 2-20.

OECD. (2003). Activity attracting, developing and retaining effective teachers. OECD.

Okoth, U. A. (2000). A study of the effects of leadership styles on performance in KCSE examination in Nairobi Province. Unpublished M. Ed. Thesis, University of Nairobi.

Okumbe, J. A. (2001). Human resource management and education perspective. Education
Development and Research Bureau.

Teri, D. M., Barbara, J. M., \& Lucindia, C. (2013). The relationship of leadership and students' achievement across societal cultures. A Journal of Social and Behavioural Sciences. 106, 3052-3061.

Wang, H., \& Guan, B. (2018). The positive effect of authoritarian leadership on employee performance: The moderating role ofpower distance. Frontiers in Psychology, 9, 357- 367.

Wangui, E. K. (2007). An investigation of how leadership styles affect performance in public secondary schools in Mathioya Division, Murang'a district. Unpublished M. E. Project, University of Nairobi.

Yahya, S. A. (2015). Leadership styles, types and students achievement in Nigeria. Doctor of Philosophy. Thesis University of Tun Hussein. Onn, Malaysia.

Yambo, J. M. O. (2012). Determinants of $K C S E$ examination performance in SDA sponsored schools: A key to academic promotion to the next level of learning. Lambert Academic Publishing.

Yusuf, A. F. (2012). Influence of principals' leadership styles on students' academic achievement in secondary schools. Journal of Innovative Research in Management and Humanities. 2(3), 110-115.

Zhao, Y. (2010). Preparing globally competent teachers: $A$ new imperative for teacher education. Journal of teacher education, 61, 421-4251. 